\title{
An Approach to the Economic Socialization of University Students: The Origin, Uses and Meaning of Money
}

\author{
Ciro Parra Moreno ${ }^{1}$, Marcela Salcedo ${ }^{1}$, María Fernanda Rebellón ${ }^{1} \&$ Ingrid Anzelin $^{1}$ \\ ${ }^{1}$ School of Education, Universidad de La Sabana, Chía, Colombia \\ Correspondence: Ingrid Anzelin, School of Education, Universidad de La Sabana, Chía, Colombia. E-mail: \\ ingrid.anzelin@unisabana.edu.co
}

Received: March 16, 2018

doi:10.5539/ies.v11n7p92

\author{
Accepted: April 30, $2018 \quad$ Online Published: June 28, 2018 \\ URL: https://doi.org/10.5539/ies.v11n7p92
}

\begin{abstract}
This article discusses the origin of university students' money, the way they use it as well as the meaning they grant it. The research that originated this discussion had a quantitative approach and descriptive scope; it was conducted among 714 Colombian university students who attended daytime classes, and it aimed at identifying the place they give to money as socializing factor. It was found that from the perspective of these young people, money is not a predominant factor in the social relations established at college and that, even when the main meaning that they attribute to money is romantic, its main use is for fun.
\end{abstract}

Keywords: social interaction, socialization, socioeconomic influences, youth, university student (ERIC Thesaurus)

\section{Introduction}

The economic life of children and young people began to be studied in the mid 1950s by sociology, developmental psychology, and economic psychology (Lauer-Leite, Colino, Da Rocha, \& Lauer, 2005). Since then, academic production has been able to theorize about the development of economic thought and to advance with more descriptive contributions in the aspects of economic socialization that affect meanings, attitudes, and economic behaviour of individuals (Rinaldi \& Bonanomi, 2011).

With regard to economic thinking, there is sufficient evidence indicating differences between the ways in which adults and children think. In the last analysis, studies conducted in the United States (Strauss, 1952, 1954; Burris, 1983), Australia (Danziger, 1958), Italy (Berti \& Bombi, 1988), Israel (Leiser, 1983), and Chile (Denegri, Lara, Córdova, \& Del Valle, 2010) identified a convergence of the developmental phases proposed by Piaget and economic thinking. Although most of these studies have been performed from a cognitive perspective, Lauer-Leite et al. (2005) indicate that there is also a line of study developed mainly by Emler (Emler \& Dickinson, 1985; Emler, 1986; Emler-Ohana \& Dickinson 1990), who, from the social representations of Moscovici, delves into the impact of shared beliefs in the social world on how to think, understand, and behave economically.

Regarding the stages in which an individual's economic thinking is developed, Denegri (1995) emphasizes three: primitive extra-economic or economic thinking, in which money is a free exchange item, and the subject is not aware about restrictions or incidence of monetary relations in the social and economic world; subordinate economic thinking, in which the subject incorporates concepts of gain, possible connection between personal relationships and those that concern the institutional-economic ones, and moral precepts in his/her way of conceiving a society ruled by laws that are required to operate and are subordinated to the common good; and economic inferential thinking, in which the subject is able to hypothesize about the economic world, establish relationships among processes, systems, and cycles, understand the multi-determination of economic and social processes, and reflect on social reality and its changes.

Berti and Bombi (1988) indicate that, although an agreement has been reached in the academic community with regard to these stages, the associated ages should not be taken ad litteram. Accordingly, Amar, Denegri, Abello \& Llanos (2002) account for the above. After conducting research in a coastal area of Colombia, they found that only $6 \%$ of the children who participated in the study reached the third level established by Denegri (1995) even though they fitted the age, and in a later study performed in 2007 by the same authors with 50 university students, aged between 19 and 24 years, they also found that only $24 \%$ of them had reached that level. 
Cross-cultural research, such as the studies conducted by Leiser, Roland-Levy, and Sevòn (1991), demonstrates the need to investigate the representations and beliefs that mediate aspects in the economic world such as wealth, poverty, and inequality, given their social and cultural complexity. Lewis, Webley, and Furnham (1995), Lauer-Leite et al. (2005), and Rinaldi and Bonanomi (2011) emphasize the necessity of enhancing the meaning assigned by subjects to economy, and the mediation that demographic variables, upbringing, social relations, plus economic, cultural, and academic conditions have on these concepts which affect the socializing process of children and young people. For Rinaldi and Bonanomi (2011), this economic socialization can be understood as the process by which individuals acquire and build skills, knowledge, and attitudes relevant to their role in the economy and, therefore, to their relationship with money.

Although research on economic socialization is limited and, above all, descriptive (Rinaldi \& Bonanomi, 2011), there are studies that identify factors that affect it such as life stage, gender, social class, family, and school. Given the limitations of the sample and the design of each of these investigations, the results presented below should not be considered conclusive and deserve further investigation.

Regarding life stage, Rinaldi (2007) suggests that the subjects enter the world of consumption earlier, focusing on not only the meaning that they give to money but also its use, given the early exposure to shopping, banking, and financial centres. In his study, Rinaldi identifies that the young Italians who participated in his study consider money to be a socializer, a tool that enables interaction and allows them to position themselves in front of their peers. However, the author stresses that it is essential to expand studies that indicate how the thinking process is developed.

Studies demonstrating the differences in financial knowledge and attitudes between male and female individuals have been prolific (Rinaldi \& Todesco 2012). Goldsmith and Goldsmith (2006) find that men report greater confidence in money management and attitudes favourable to investment than women; Hira and Mugenda (2000) report that in terms of financial behaviour, women use more cautious investment strategies. Chen \& Volpe (1998) and Rinaldi and Todesco (2012) indicate that these differences may be partially caused by the socialization models to which men and women are exposed to and their financial literacy.

Other elements that seem to influence comprehension, attitude, and behaviour are the subjects' exposure to scenarios in which there is monetary exchange, such as those between parents and clients (Berti \& Bombi, 1988), the beliefs and conceptions of parents or caregivers about economy (Lunt \& Furnham, 1996), the extension of the child's experience from the administration of an early age allowance (Marshall \& Magruder, 1960), parental economic behaviour, discussion of economic issues with children, and parental guidance over the future (Webley \& Nyhus, 2006, cited by Lauer-Leite et al., 2005).

Nevertheless Lauer-Leite et al. (2005) indicate that social class is a highly complex factor and, therefore, studies' outcomes are divergent, it is another element to be considered. Authors claim that even though there are studies evidencing differences between economic socialization and economic practices among individuals of different social classes, they have also found these differences among individuals of the same social class. Now, it is possible to trace studies that show relationships between social class and economic conceptions; in a study conducted in England by Furnham (1982), it is found that upper-class students tend to see poverty as the result of the individual's own action or non-action, whereas lower-class social students are keen to explanations of social order, which attribute the responsibility of the economic situation of individuals to institutions. On the other hand, Berti and Bombi (1988) state that social class is part of a more complex variable called living space, understood as environments such as school, home, or country, that impact on specific experiences in the construction of economic reality at a certain age.

Schwarz (1992, cited by Rinaldi \& Bonanomi, 2011) affirms that money, has an ambivalent nature because it can be considered to be a value for people to justify actions and evaluate situations and people, or a tool to achieve other types of values such as social esteem, love, or security.

Damay and Guichard (2016) provide an overview of the skills and processes related to price and the propensity of children to engage in trade. However, there is a need to understand the meaning of money for children and young people at present, partly because new research evidence has questioned beliefs about what it means for this age group and their economic behaviour. Rinaldi \& Bonanomi (2011) conduct an exploratory study with Italian adolescents, finding that far from what is believed, they seem less materialistic than popular opinion and the media often report. As De Singly (2008, cited by Rinaldi \& Bonanomi, 2011), claims that contemporary youth seems to be aware that they need material, social, and psychological support to develop their potential, and they seek this support in their family and in affective relationships with their peers.

In contrast, Pyöriä, Ojala, Saari, and Järvinen (2017) call attention to the need to understand what is presently 
occurring with the new generations, such as the so-called Millennial. Researchers note that in Finland, far from what is believed, this generation values work as much as older generations; this occurs because these young people are more flexible and are more willing to change to different occupational fields. Another study, conducted by Lewis and Scott (2000), finds that university students presently seem to have more tolerant attitudes toward debt and access to credit. This makes sense if we consider Karl Mannheim's ideas (cited by Pyöriä et al., 2017), who emphasizes that these are possible effects of a generation that, more than any other, has socialized in an uncertain and fluctuating economic and labour market. It is then highlighted how globalization has modified consumption patterns and ability to access goods and services, especially by young people, impacting their place in the socioeconomic order and, therefore, their identity (Denegri, Martínez, \& Etchebarne, 2007).

From the literature reviewed, it is identified that little is known about the economic socialization of young people, mainly in their passage through university. Hence, the interest of researchers is to broaden the view on social interactions and human nature in terms of its economic dimension and the place given to money in interaction and social exchange.

This article discusses the origin of university students' money, the way they use it, and their perception of it as a socializing factor. However, recognizing the influence of context on the socialization process (Rinaldi \& Bonanomi, 2011), some elements are included in such a way as to allow a description of the scenario in which socialization processes of the participant students take place.

\subsection{Higher Education in Colombia}

Higher Education is part of the formal education system in Colombia. In order to access it, a person must have completed elementary and secondary education, which lasts approximately 11 years (Rojas, 2006). The undergraduate level in Higher Education is composed of three levels of training or education: technical, technological and professional, being this latter offered by universities (Melo, Ramos, \& Hernández, 2014). From the universe of students registered in higher education in Colombia, $32 \%$ are in Bogota, capital city of Colombia, according to the National Higher Education Information System of the Colombian Ministry of Education (SNIES, 2017).

In Colombia, just a little more than half of every 100 high school graduates enrol in higher education (López, 2014). Students coming from a high economic position have less difficulty entering private universities and completing their studies (Altbach, Roa, \& Pacheco, 2013), a fact confirmed by Amaya (2002) who indicates that three out of four enrolled students come from the top $40 \%$ of the population with higher economic status, while one out of forty comes from the poorest $20 \%$ (p.11).

Even when there is a public offer that minimizes tuition costs, there are indirect maintenance expenses that sometimes refrain families from sending their children to follow university studies due to the fear of getting into debts (Altbach, Roa, \& Pacheco, 2013). Hence, permanence in the educational system implies socioeconomic conditions that in many cases families cannot guarantee (López, 2014).

Likewise, a recurrent feature in this country's public Higher Education Institutions - IES, Spanish acronym - is that a large part of the programs offered requires exclusive dedication, and the benefits acquired only cover enrollment. In this sense, young people are forced to decide whether to work or study. As a result, many of them begin university studies but only a few can really finish. (López, 2014, p. 254).

Similar to other Latin American countries such as Brazil, IES' world is not homogeneous and there are universities oriented to the upper and upper middle classes that generally involve high costs for students. Although these institutions are characterized for delivering classes during daytime (Lovisolo \& Tavares, 2014), public universities also do so. In addition, the low majors' offer on night schedules or distance programs for people who must simultaneously work and study, it has been increasing despite the Ministry of Education's own fear that such programs would undermine the quality of the education process.

By 2015, the indicators of the National Higher Education Information System of the Colombian Ministry of Education-SNIES, Spanish acronym- evidenced that the coverage rate in Colombia was $43 \%$ approximately. But that Colombian rate is relatively low when compared to developed countries such as the United States, Finland, Spain, New Zealand, Australia, and Norway, and to a group of Latin American countries such as Argentina, Chile, Cuba, and Uruguay, whose coverage rates exceeded 60\% (Melo, Ramos, \& Hernández, 2014, p. 12).

In Latin America, Tünnermann (2000, quoted by Ortíz \& Morales, 2011) indicates that massification has been related to the belief of social assent and sociopolitical development of State (World Bank, 2000), so governments will continue developing future actions to expand coverage. Therefore, universities will become a socialization space that, over the years, will include more young people from the region. 


\section{Method}

The research was conducted in Bogota, Colombia. It is a quantitative, non-experimental, descriptive study, with a sample of 714 young people from nine daytime public and private Higher Education Institutions (IES), who had training programmes in four areas of professional training: health sciences, engineering, economics, and social sciences and humanities (Table 1). Data were collected during 2014.

Table 1. Sample of university students

\begin{tabular}{lcccc}
\hline University & Student Population & Suggested Sample & Students & \% Sample \\
\hline Nacional & 23.355 & $80-120$ & 120 & 16.8 \\
Distrital & 10.384 & $60-100$ & 63 & 8.8 \\
Minuto De Dios & 3.899 & $30-50$ & 34 & 4.6 \\
Javeriana & 27.357 & $80-120$ & 116 & 16.2 \\
Rosario & 8.929 & $60-100$ & 82 & 10.1 \\
La Salle & 14.587 & $60-100$ & 72 & 11.5 \\
Los Andes & 12.684 & $60-100$ & 108 & 15.1 \\
La Sabana & 6.762 & $40-60$ & 60 & 8.4 \\
Externado De Colombia & 5.536 & $40-60$ & 61 & 8.5 \\
\hline
\end{tabular}

Source: National System of Higher Education (2014).

$55.4 \%$ of the surveyed population is between the first and fourth semesters (first cycle), $35.3 \%$ is between the fifth and eighth semester (second cycle), and $9.3 \%$, is in the third cycle.

As shown in Table 2, the survey addressed the following topics:

Table 2. Topics of inquiry

\begin{tabular}{|c|c|c|c|}
\hline Topic & Description & Classification & \\
\hline $\begin{array}{l}\text { Origin } \quad \text { of } \\
\text { money }\end{array}$ & $\begin{array}{l}\text { Amount and origin of the } \\
\text { money that university students } \\
\text { manage other than tuition costs }\end{array}$ & & \\
\hline \multirow[t]{6}{*}{ Use of money } & & Basic & $\begin{array}{l}\text { Subsistence. Satisfaction of everyday needs such as } \\
\text { transportation, food, housing, and clothing. }\end{array}$ \\
\hline & & & $\begin{array}{l}\text { Academic. Responds to the needs for tools for developing } \\
\text { activities in academic spaces. }\end{array}$ \\
\hline & $\begin{array}{l}\text { Exchange to obtain some good } \\
\text { or service (Olivella, 2010) }\end{array}$ & Tools & $\begin{array}{l}\text { Acquiring, renting, or maintaining equipment such as } \\
\text { computers, calculators, tablets, and cell phones, among others, } \\
\text { that are not mandatory. These costs increase efficiency and } \\
\text { competitiveness. (Bok, 2010). }\end{array}$ \\
\hline & & Fun & Recreational activities \\
\hline & & Solidarity & $\begin{array}{l}\text { Sharing with others and supporting them in their needs. } \\
\text { (Rodríguez, Bernal \& Urpi, 2005) }\end{array}$ \\
\hline & & Saving & Reserving or saving. \\
\hline \multirow[t]{6}{*}{$\begin{array}{l}\text { Meaning } \\
\text { money }\end{array}$} & $\begin{array}{l}\text { Relationship between things } \\
\text { and experience (Locke, 1689; } \\
\text { Gaarder 1991) }\end{array}$ & Solidary & $\begin{array}{l}\text { Sharing with others, \& supporting them in their needs } \\
\text { (Rodríguez, Bernal \& Urpi, 2005). Permanent support provided } \\
\text { by or for them (Núñez, 2002). }\end{array}$ \\
\hline & & Subsistence & $\begin{array}{l}\text { Tools that allow goods and services such as housing, food, } \\
\text { clothing, and transportation (Ramos, 2010) }\end{array}$ \\
\hline & & Power & $\begin{array}{l}\text { Influence on the representations and actions of others. } \\
\text { (Foucault, 2005) }\end{array}$ \\
\hline & & Social acceptance & $\begin{array}{l}\text { Mean that facilitates inclusion and integration with peers, as } \\
\text { well as to maintain and transcend social relations (Osuna, 2008) }\end{array}$ \\
\hline & & Romantic & $\begin{array}{l}\text { Personal, cognitive, social, and intellectual development (García } \\
\text { de Quijano, 2000) }\end{array}$ \\
\hline & & Vital & $\begin{array}{l}\text { Mechanism to solve problems and overcome difficulties } \\
\text { (Scheler, 2001) }\end{array}$ \\
\hline
\end{tabular}




\begin{tabular}{llll}
\hline & & Tool for personal satisfaction (Von Mises, 1936; Jorgen \\
& & Hedonistic & Pedersen, 1960) and individual wellbeing (Millan, 1974). \\
Socialization & College students as members of & $\begin{array}{l}\text { Sports } \\
\text { particular college groups }\end{array}$ & Cultural Solidarity \\
groups & Academic Religious & \\
& (Quintana, 1997) & Friendship & \\
\hline
\end{tabular}

Source: Authors' own survey.

For each topic element, a maximum number of items was defined, using Likert scale, multiple choice, and double entry tables, and a pilot study was conducted at the University of La Sabana, validating the structure and understanding of the final tool.

All data were processed using the IBM-SPSS Statistics 20 statistical software. Non-parametric tests were used for comparison between two independent samples using the Mann-Whitney $U$ test, and for a larger number of samples, the Kruskal-Wallis test was used. Structural analysis of correlations was performed by calculating the Spearman's rank correlation coefficient. To assess the operationalization of the variables related to uses, a rotation factorial analysis with the socialization and meaning groups was performed using Varimax 4.5.1.

\section{Results}

\subsection{Sources of the Economic Income of University Students}

Regarding monthly amount, $20.97 \%$ of the young respondents indicated that they managed less than 70 dollars, $38.47 \%$ between 70 and 130 dollars, $24.31 \%$ between 130 and 200 dollars, $8.47 \%$, between 250 and 330 dollars, and $2.5 \%$ more than 330 dollars. According to the students, $90.6 \%$ of them depend on their families for the money. Some $20 \%$ indicated that in addition to family support, they increase their income by working, and $4.3 \%$ noted that they receive grants and financial support.

Comparing these results with those of the University of Michigan (2012), it is found that the family financing of Bogota students exceeds North American students by 30 percentage points. The high percentage of students depending on family allowance as income for university expenses in Bogota might occur as long as they exist both, the social moratorium in the middle and upper classes, and the difficulties in accessing the labour market in quality jobs without the required proper educational credit.

Within the $20 \%$ respondents who claim they work to have additional income, it is found that $8 \%$ have weekend jobs, $7.7 \%$ part-time and daytime jobs, $2.5 \%$ work in the university, and $5.5 \%$ sell products and work for fellow students. If the percentage of students from Bogota who simultaneously work and study, is compared to what is reported by the financial aid office of the University of Buenos Aires (2004), Argentinian students overcome this figure by 40 percentage points. It is worth noting that this estimate would certainly change if the sample were extended to college students attending mixed day-night or night-time classes.

From the above, it is highlighted that the economic support factor for different activities performed by college students of Bogota is shaped by the family allowance as the main source of financing. Similarly, students attend an atmosphere ruled by low employment rates in which part-time and weekend works out of the university predominate. As for the comparison made with other Latin American students, it can be stated that the students who participated in the study have less economic independence and greater moratorium.

\subsection{What University Students Spend Money On}

The results are expressed using an identical scale that allows evaluation, association, and/or comparison with the different categories of the study. In the case of uses, a representative percentage value was created for the amount received and the amount spent based on the monthly income previously indicated by each student (Table 3). 
Table 3. Distribution of uses

\begin{tabular}{|c|c|c|c|c|c|c|}
\hline & \multicolumn{6}{|c|}{ Uses } \\
\hline & Basic Academic & Basic Subsistence & Fun & Tools & Solidarity & Savings \\
\hline \multirow{2}{*}{$\mathrm{N}$} & 714 & 714 & 714 & 714 & 714 & 714 \\
\hline & 0 & 0 & 0 & 0 & 0 & 0 \\
\hline Mean & 31.927 & 57.990 & 69.392 & 8.757 & 2.165 & 16.733 \\
\hline Median & 18.75 & 50.666 & 50 & 2.5 & 0 & 7.5 \\
\hline Standard deviation & 46.578 & 71.071 & 72.459 & 13.275 & 13.495 & 46.104 \\
\hline Asymmetry & 6.025 & 17.079 & 3.355 & 2.762 & 12.843 & 14.811 \\
\hline Asymmetric Standard Error & 0.091 & 0.091 & 0.091 & 0.091 & 0.091 & 0.091 \\
\hline Kurtosis & 59.721 & 382.017 & 20.05 & 11.397 & 199.422 & 295.697 \\
\hline Kurtosis Standard Error & 0.183 & 0.183 & 0.183 & 0.183 & 0.183 & 0.183 \\
\hline Minimum & 0 & 0 & 0 & 0 & 0 & 0 \\
\hline Maximum & 665 & 1680 & 760 & 100 & 250 & 1000 \\
\hline \multicolumn{7}{|l|}{ Percentiles } \\
\hline 25 & 8.519705 & 33.333333 & 23.480392 & 0 & 0 & 0 \\
\hline 50 & 18.75 & 50.666667 & 50 & 2.5 & 0 & 7.5 \\
\hline 75 & 39.464 & 70 & 91.666 & 13.625 & 0 & 20.982 \\
\hline
\end{tabular}

Source: Authors' own survey.

It was found that the greatest reported use was for Fun at 69.39 points, followed by Basic Subsistence and Basic Academic use at 57.99 and 31.92 points, respectively. Savings was 16.73 points, and the use for Tools was 8.75 points; the lowest use indicated was Solidarity at 2.16 points.

Comparing Basic Academic use by study cycles, in the third cycle, it ranked at 25.5 points, followed by the first cycle at 18.8 points and the second cycle at 16.0 points. The use for Basic Subsistence was relatively stable during the three cycles, with an average value of 52 points.

Solidarity use for this analysis is valued at 0.0 points according to the median of the university students from the different cycles. If use is analyzed regarding gender, women value Basic Academic use (22.5), Basic Subsistence (53.3), and Tools (4.7) the highest, whereas men assigned 15.0, 50.0, and 1.9, points, respectively. On the other hand, men rated Fun (53) higher than women did (46.7).

Finally, if use by area of study (vocational training) is compared, a greater difference in Fun and Basic Academic use is found. Economics' students valued Fun at 68 points, followed by Social Sciences and Humanities' students at 63 points, Engineering's students at 43 points, and Health Sciences' students at 39 points. Academic use was the most highly valued use by Social Sciences and Humanities' students at 27 points, followed by Health Sciences', Economics', and Engineering's students at 17, 16, and 14 points, respectively.

As shown in Table 4, the Mann-Whitney $U$ test and the Kruskal-Wallis test indicated that there are significant differences among use for Basic Academic, Fun, Tools, and Savings at an institutional level. The Basic Academic use differs according to gender, while basic academic use, fun use and savings use differ by study area.

Table 4. Comparison of the use of money according to variables' analysis

\begin{tabular}{|c|c|c|c|c|c|c|c|}
\hline & & \multicolumn{6}{|c|}{ USES } \\
\hline & & Basic academic & Basic subsistence & Fun & Tools & Solidarity & Savings \\
\hline \multirow{4}{*}{ 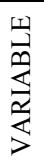 } & Institution & $\mathrm{X}$ & $=$ & $\mathrm{X}$ & $\mathrm{X}$ & $=$ & $\mathrm{X}$ \\
\hline & Cycle & $=$ & $=$ & $=$ & $=$ & $\mathrm{X}$ & $=$ \\
\hline & Gender & $\mathrm{X}$ & $=$ & $=$ & $=$ & $=$ & $=$ \\
\hline & Study area & $\mathrm{X}$ & $=$ & $\mathrm{X}$ & $=$ & $=$ & $\mathrm{X}$ \\
\hline
\end{tabular}

$\mathrm{X}$ : Distribution of the use indicator is different for each of the groups

$=$ : Distribution of the use indicator is equal for each of the groups.

Source: Authors' own survey

Comparing the use of money with its origin, there were significant differences in Basic Subsistence use and Fun 
use among students who receive family allowance and for students who perform some type of work. For those who receive their support from scholarship income, this difference is identified in use for Basic Academic, Basic Subsistence, Fun, and Savings.

With respect on the way money is used, it is found that in addition to the expected Basic Subsistence use, there are significant differences in Fun and Savings, being the students of private universities who spend more on Fun. These differences could be explained by the difference in socioeconomic origin of the students and by the fact that the public university focuses on academic (in relation to fun) performance. Returning to Zelizer (2005), these monetary practices would be symbolically and socially differentiated, and the reported monetary circulations make it possible to understand the social bonds they support.

\subsection{Meaning of Money for College Students}

The questions of this topic were formulated to determine the students' level of agreement with phrases that expressed the seven meanings of money using a Likert scale. For the analysis, the results were converted into a value scale ranging from 0 to 100 that organizes students' responses, bearing in mind that some meanings corresponded to more than one question.

As shown in Table 5, it was found that for university students, the meaning with the highest value was Romantic at 79 points, followed by Hedonist at 69 points. Solidarity and subsistence follow, with values of 50.9 and 50.3 points, respectively. The Vital meaning was valued at 41.6 points, and Power was 26.8 points. The meaning of Social Acceptance had the lowest value at 14.2 points.

Table 5. Distribution of meanings

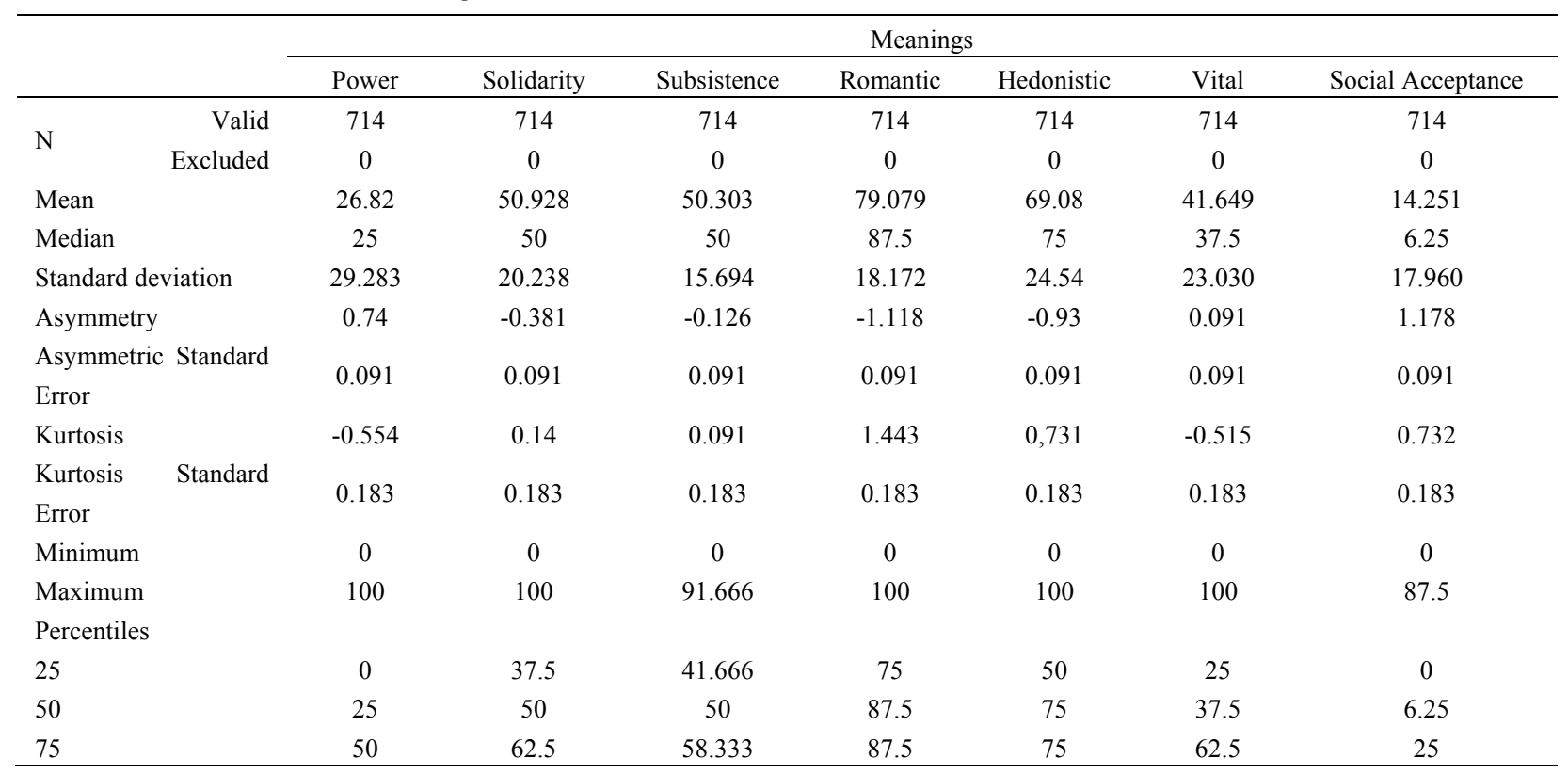

Source: Authors' own survey.

Comparing the meaning of money by type of university, Power was valued at 25 points by students of private universities versus 0 points by students of public universities. The Romantic category was valued by students of private universities at 87.5 points, whereas students of public universities valued it at 75 points. Social acceptance was also different between university types, with private university students valuing this meaning at 12.5 points and public university students at 0.0 points.

Regarding gender differences, it was noted that men rated the Power meaning at 25 points and Social Acceptance at 12.5 points (versus 0.0 indicated by women for both) and that women assigned more value to the Romantic meaning at 87.5 points versus the 75 points indicated by men.

Now, regarding the relationship between the meaning and the origin of student money, it was found that there is difference in the meaning of Subsistence and Solidarity between the students who obtain their money from a family allowance and those who work to obtain it. In the case of students receiving financial aid, such as 
scholarships, the meaning of Social acceptance has a significant difference with respect to how the other groups of students rate it.

It was noted that the meaning that the students gave to money is not directly related to how they report they use it. Thus, although a Romantic meaning ranked highly, the students actually reported a use focused on Subsistence and Fun. That is, university students indicated that they used their money for social needs even though the meaning that they gave to its use was not directly related to elements of socialization.

\subsection{Socialization Groups}

To examine whether money had an influence on the economic socialization of young university students, they were asked about the degree of non-participation or exclusion due to a lack of money. To quantify this aspect, two measurement indices expressed on a scale of 0 to 100 were created.

The students rated the exclusion index due to a lack of money at 4.0 points and the non-participation index at 6.8 points. The values reported for this question are low, which indicates that in general terms, the economic factor does not play a significant role in socialization, since university students do not feel excluded nor have they stopped participating within socialization groups.

However, from the use of the box plot (Figure 1), which displays outliers, there are some cases of students reporting having felt excluded from the socialization groups and not being able to participate in them according to topics related to money.

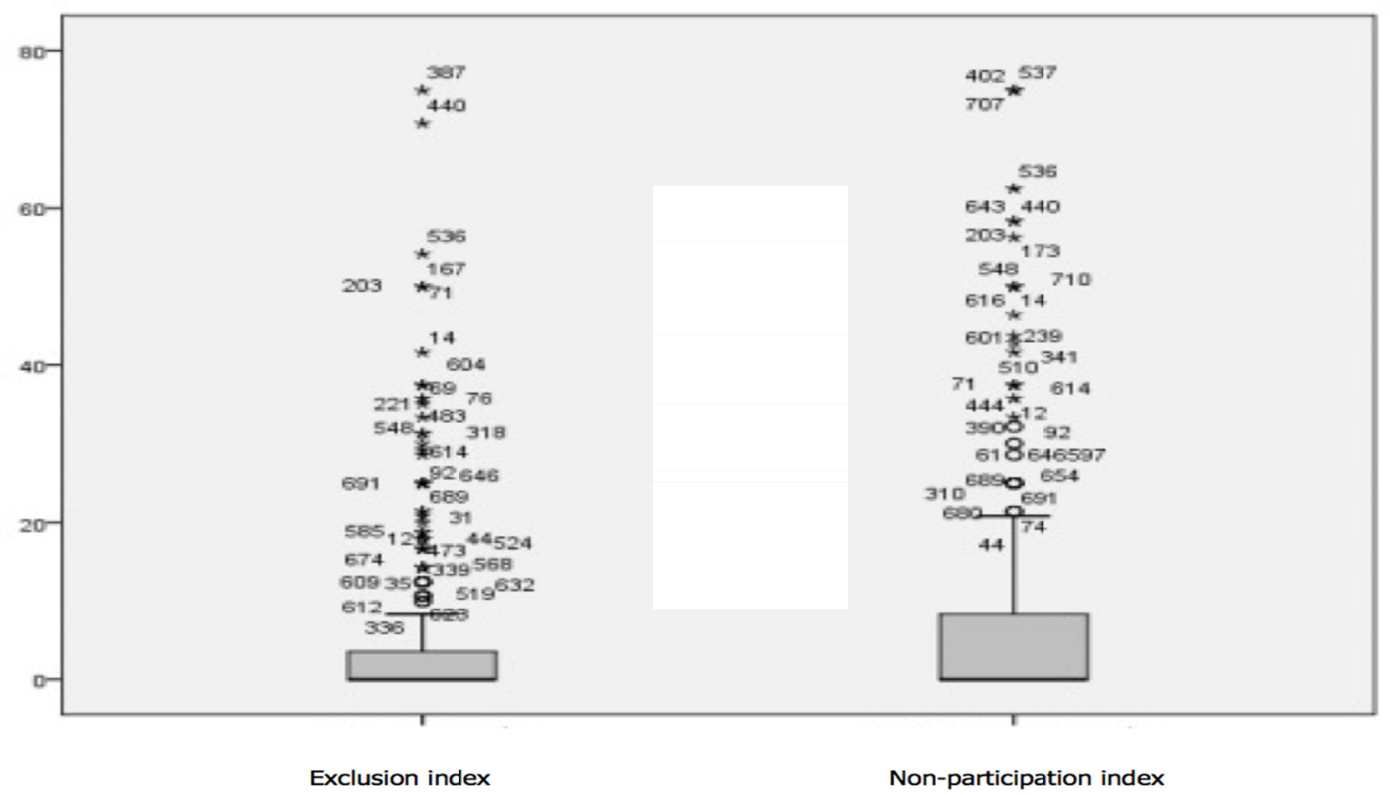

Figure 1. Box plot of indices

In spite of the above, the results of the exclusion and non-participation indices may lead to the conclusion that, without ignoring the existence of money, this is not such a relevant factor for the development of the social being at university.

It appears that in the process of socialization in university groups such as sports, cultural, solidarity, academic, religious and fun groups, students do not need money to be part of them or that there are other types of skills or abilities that can weigh more than money in these groups.

\subsection{Correlations between Uses and Meanings}

In evaluating the correlation between the different categories of uses and meanings, correlations between use for fun and the hedonistic, life stage, and social acceptance meanings of $0.110,0.126$, and 0.142 , respectively, were found. Simultaneously, there was a correlation between tool use and life stage meaning of 0.119 and equally between tool use and social acceptance meaning of 0.111 . Solidarity use and the solidarity meaning had a correlation of 0.154 . The basic academic use and basic subsistence use as well as the power, subsistence, and 
romantic meanings were not correlated.

\subsection{Correlations between Uses, Meanings, and Indices}

Correlating the categories of uses, meanings, and socialization groups with their indices, the following correlations were found: between Savings and Fun uses, the correlation was 0.152. Between the Exclusion index and the Non-Participation index, the correlation was 0.580. Between the Exclusion index and the Power meaning, the correlation was 0.114. Between the Exclusion index and Social Acceptance meaning, the correlation was 0.155. Between the Non-Participation index and Social Acceptance meaning, the correlation was 0.134. Finally, Hedonistic, Subsistence, Romantic, Vital (Life), and Solidarity meanings and uses for Basic Academic, Basic Subsistence, Tools, and Solidarity are not correlated in any way (Figure 2).

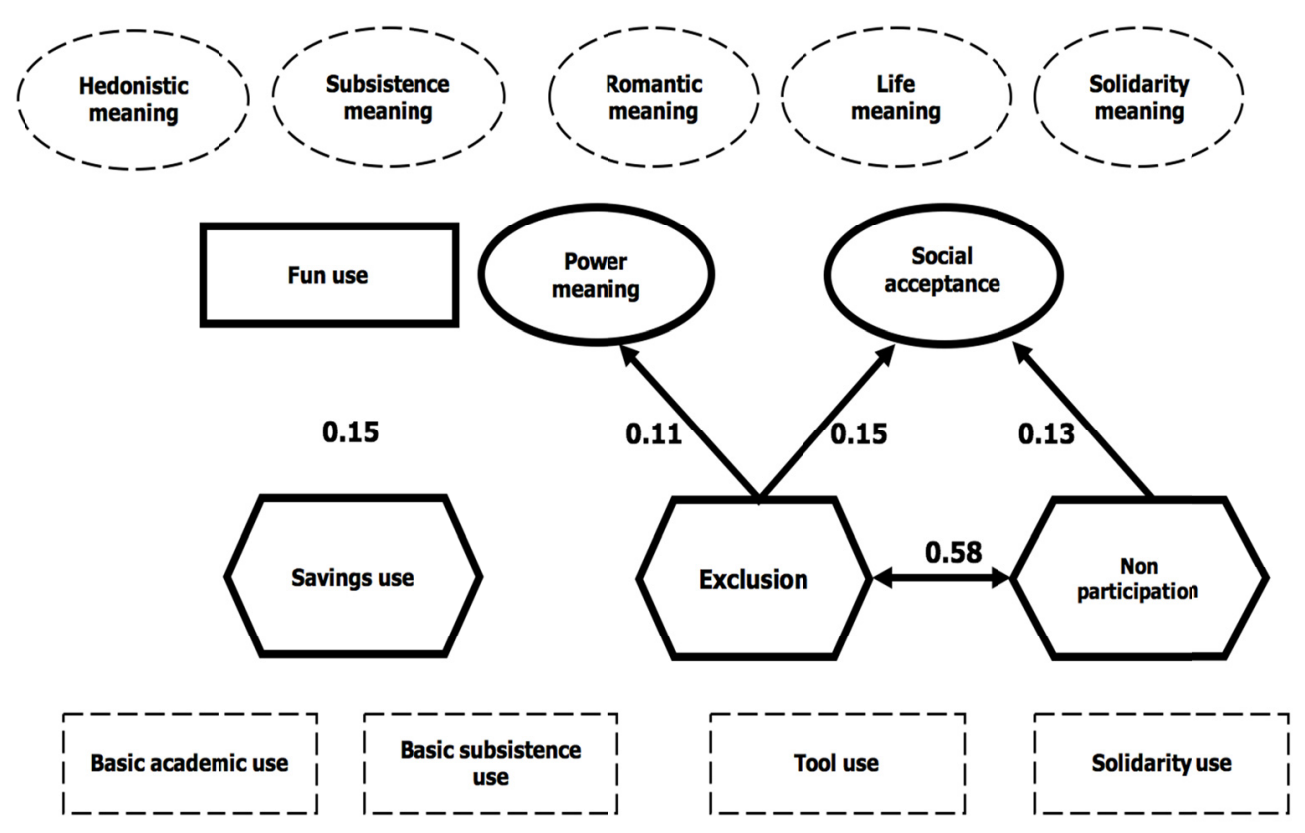

Figure 2. Correlations between uses, meanings, and indices

\subsection{Correlations between Meanings}

Relating the seven meanings, as shown in figure 3, the strongest correlation is the Social Acceptance-Power meanings at 0.537 , followed by the Vital (Life)-Social Acceptance, and Vital (Life)-Power meanings at 0.420 and 0.419 , respectively. The hedonistic-Vital (Life) and Hedonistic-Power meanings have a correlation of 0.313 and 0.310 , respectively. The Solidarity-Romantic relationship is 0.241 , and the Subsistence-Vital (Life) relationship is 0.240 .

Regarding inversely proportional correlations, we find that Romantic meaning and Social Acceptance are inversely correlated with a value of -0.323 , Romantic and Vital (Life) with a value of -0.272 , and Romantic and Power with a value of -0.241 . 


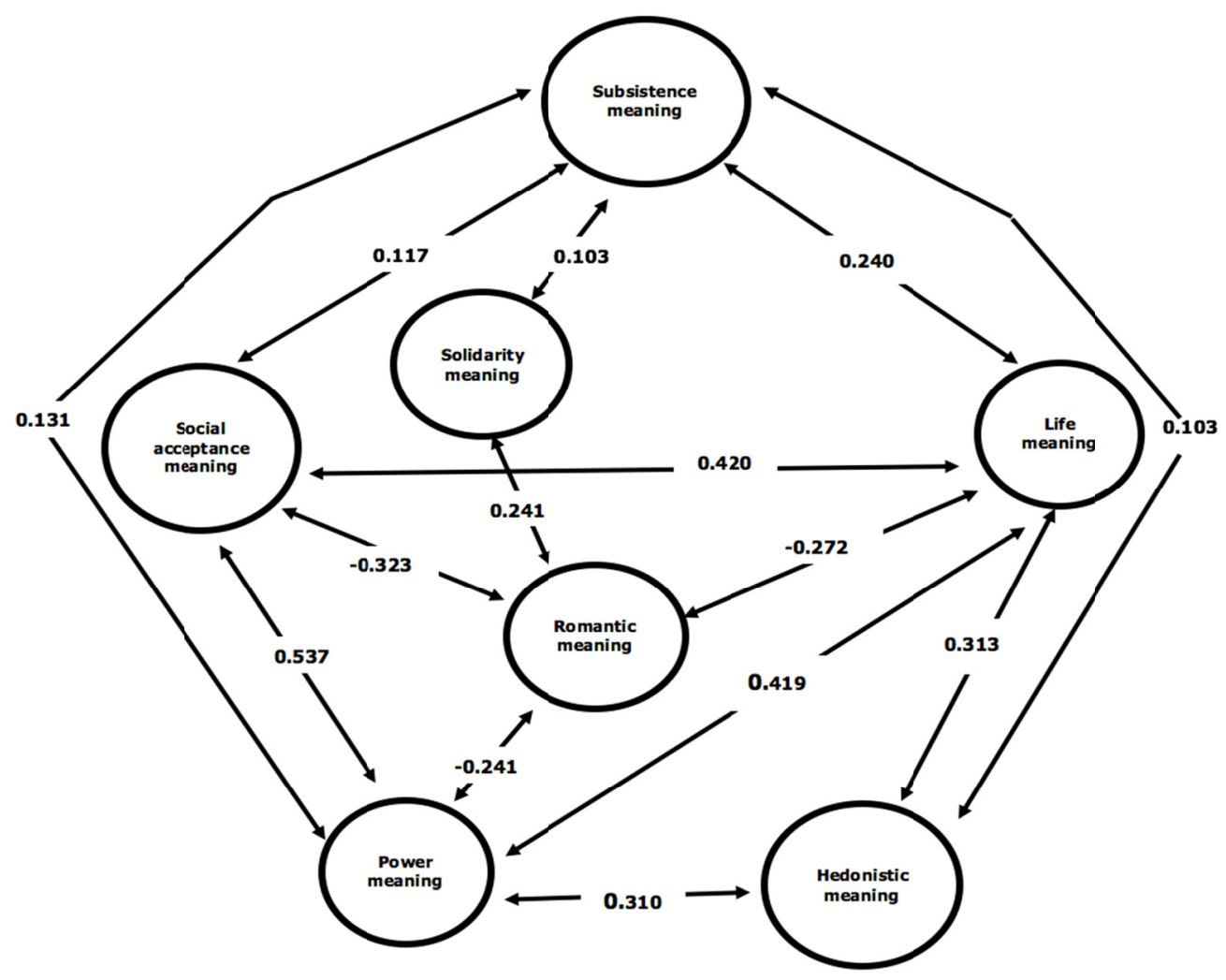

Figure 3. Correlations between meanings (Source: Authors' own survey)

\section{Discussion of Results}

According to the analyses of each category, for the Bogota students surveyed, the main use of money is for subsistence and fun, and the main meaning is romantic. These results seem to indicate that for students, although money is a tool designed for their personal development, they use it for basic elements such as food and transportation as well as in events related to social exchange.

These outcomes also indicate that although money is not determinant, it could be thought of as a factor present in the social process that generates and nurtures permanence, transcendence, and stability in the different relationships of the young adults, which reinforces the thesis proposing money as an element that is part of the construction of social interactions and as an element that facilitates socialization even when the young person is not particularly aware of it. Thus, as Zelizer (1994) suggests, money seems to be an implied and necessary instrument in social relations.

On the other hand, the correlation analysis of the romantic meaning, which predominates in students (79.1 points), is presented as the only meaning with negative correlations associated with the meanings of social acceptance, life stage, and power. This correlation can highlight the contrast of students who rank in thinking levels I and II on Denegri (1995) scale; that is, those who have an extra-economic or primitive thinking for whom money is an instrument of free exchange that is not associated with setting up relationships in the social and economic world, versus students who even at a level of subordinate economic thinking perhaps too early identify the relationship between personal and institutional-economic levels, incorporating moral precepts into their way of conceiving a society ruled by laws that are necessary for its functioning.

Zelizer (1994) proposes the concept of the multiplicity of money, which indicates that a value other than the same amount of money depends on the social interaction that it generates, meaning that the function attributed to money depends more on the destination than on the quantity. This is the case of the difference found between the use and the meaning of solidarity. Whereas use was reported to be low (2.2 points), its meaning occupies a place of priority (third place with 50.9 points), showing a distance between the ways of conceiving and acting or perhaps showing that the highly valued meaning is due to some solidarity action performed or received during students' educational life. 


\subsection{Concluding Hypotheses}

The following are the proposed conclusions that attribute a relative value to the studied phenomenon, which must be interpreted by virtue of the highly dynamic, contingent, and complex nature of the studied object and the particular composition of the sample, which, as presented, only represents the percentage of young people who manage to enter a university in Colombia.

Bogota's daytime university students are not economically autonomous. Family allowance is their main source of income (90\%), and the majority of students have a monthly income between 70 and 130 dollars. This situation evidences that the sample of Bogota students is almost exclusively dedicated to studying; only $10 \%$ of them have entered the labour market or, at least, developed activities that generate an income additional to that provided by the family.

As indicated by Margulis and Urresti (1996), this portion of the social group is being supported by an adult group that, by delaying their entry to the labour world, may have in the future more and better development of competences according to the new challenges of the production and social division of labour. This moratorium period, in addition to providing training and learning spaces, also includes leisure time and activities that complete their cultural and social education.

Money in the college world is a tool that facilitates life, particularly if it originates from scenarios other than earning it, which explains why it is possible to observe a glimpse of tranquility or romanticism in most of the chosen indicators of meaning and use. However, in contrast to young people who have a limited allowance from their families or because it comes from their work, there is evidence of a greater degree of awareness regarding its origin, expenditure, and profit as well as its impact on social relations.

The study identifies aspects that affect the way in which the student uses money as a socialization tool. Regarding indicators that involve elements of interaction, such as fun and solidarity (in the 'use' category), and social power and acceptance (in the 'meaning' category), results are not as conclusive as they are at demonstrating how these individuals prioritize the monthly use of the resources that they depend on and that they are able to mobilize in the socialization scenario investigated here, higher education.

\section{References}

Altbach, P, Roa, A, \& Pacheco, I. (2013). Educación superior en Colombia: doce propuestas para la próxima década [Higher education in Colombia: twelve proposals for the next decade]. Barranquilla, Colombia: Universidad del Norte.

Alvarado, S., \& Vommaro, P. (2010). Jóvenes, cultura y politica en América Latina: Algunos trayectos de sus relaciones, experiencias y lecturas 1960-2000 [Young people, culture and politics in Latin America: Some paths of their relationships, experiences and readings 1960-2000]. Rosario, Argentina: HomoSapiens.

Amar, A., Abello, Ll., Denegri, M., \& Llanos, M. (2006). Análisis de las representaciones acerca de la economía en jóvenes universitarios del caribe colombiano [Analysis of the representations on economy by young university students of the Colombian Caribbean]. Investigación y Desarrollo, 14, 152-173. Retrieved from http://rcientificas.uninorte.edu.co/index.php/investigacion/article/view/953/571

Amar, A., Abello, Ll., Denegri, M., \& Llanos, M. (2007). Pensamiento económico en jóvenes universitarios [Economic thinking in university students]. Revista latinoamericana de psicologia, 39, 363-373. Retrieved from https://dialnet.unirioja.es/descarga/articulo/2539797.pdf

Amar, J., Denegri, M., Abello, R., \& Llanos, M. (2002). Pensamiento económico de los niños colombianos: Análisis comparativo en la región Caribe [Economic thinking of Colombian children: Comparative analysis in the Caribbean region]. Colombia: Uninorte.

Amaya, G. (2002). Cobertura e inequidad. Educación Superior en Colombia [Coverage and inequity. Higher Education in Colombia]. Educación y Educadores, 5, 9-20. Retrieved from http://educacionyeducadores.unisabana.edu.co/index.php/eye/article/view/508/1595

Angulo, L. (2010). Circulación, usos y significados del dinero en mujeres usuarias de Microcréditos [Circulation, uses and meaning of money in female users of Microcredit]. Revista de estudios de género, 4, 117-176. Retrieved from http://www.scielo.org.mx/scielo.php?script=sci_arttext\&pid=S1405-94362010000200006\& lng $=$ en\&tlng=en\#?

Arango, G. (2004). La Educación Superior en Colombia. Análisis y estrategias para su desarrollo [Higher education in Colombia. Analysis and strategies for its development]. Bogotá: Editorial Universidad Nacional de Colombia. 
Arango, L. (2006). Jóvenes en la universidad: Género, clase e identidad profesional (20th ed.) [Young people in the university: Gender, class and professional identity]. Bogotá: Century of Man Publishers.

Araujo, A., García, M., De Arteaga, J., Sierra, A., Dorado, A., Gómez, J., \& Vanegas, B. (2000). Juventud (2nd ed.) [Youth]. Bogotá: Universidad de la Sabana.

Berti, A., \& Bombi, A. (1988). The Child's Construction of Economics. Cambridge, University Press.

Bilbao, A. (2000). El dinero y la libertad moderna [Money and modern freedom]. Revista Española de Investigaciones Sociológicas, 89, 119-139. https://doi.org/10.2307/40184228

Bok, D. (2010). Universidades a la venta: La comercialización de la educación superior [Universities for sale: Marketing of higher education]. Valencia: Universitat de Valéncia.

Brunner, J. (2012). La idea de universidad en tiempos de masificación [Idea of university in the massification era]. Revista Iberoamericana de Educación Superior (RIES), 3, 139-144. Retrieved from https://www.researchgate.net/publication/279444871_La_idea_de_universidad_en_tiempos_de_masificacio $\mathrm{n}$

Chen, H., \& Volpe, R. P. (1998). An analysis of personal financial literacy among college students. Financial Services Review, 7, 107-128. https://doi.org/10.1016/S1057-0810(99)80006-7

Damay, C., \& Guichard, N. (2016). The role of price in the socialisation of children as consumers. Recherche et Applications en Marketing, 31, 64-84. https://doi.org/10.1177/2051570715626368

Denegri, M. (1995). El desarrollo de las ideas acerca de la emisión monetaria en niños y adolescentes: Estudio exploratorio [Development of ideas about monetary issues in children and adolescents: Exploratory study]. Revista del Instituto de Ciencias de la Educación, 9(1), 47-62. Retrieved from http://www.scielo.org.co/scielo.php?script=sci_nlinks\&ref=000100\&pid=S1657-926720150001000160001 $1 \& \operatorname{lng}=\mathrm{en}$

Denegri, M. (1998). Introducción a la Psicología Económica [Introduction to Economic Psychology]. Barcelona: PSICOM Publishers.

Denegri, M., Lara, M., Córdova, G., \& Del Valle Rojas, C. (2008). Prácticas de ahorro y uso del dinero en pre adolescentes (Tweens) Chilenos [Savings practices and use of money in Chilean pre-teenagers (Tweens)]. Revista Universum, 23, 24-38. https://doi.org/10.4067/S0718-23762008000100003

Denegri, M., Martínez, G., \& Etchebarne, S. (2007). La comprensión del funcionamiento bancario en adolescentes chilenos: Un estudio de psicología económica [Understanding banking operation by Chilean adolescents: A study of economic psychology]. Interdisciplinaria, 24, 137-159. Retrieved from https://www.researchgate.net/publication/26545533_La_comprension_del_funcionamiento_bancario_en_ad olescentes_chilenos_Un_estudio_de_Psicologia_Economica

Elster, J. (2010). La explicación del comportamiento social [Explanation of social behaviour]. Barcelona: Editorial Gedisa.

Foucault, M. (1988). El sujeto y el poder [Subject and power]. Revista Mexicana de Sociología, 50(3), 3-20. https://doi.org/10.2307/3540551

Foucault, M. (2005). Las palabras y las cosas (32nd ed.) [Words and things]. Ed. Mexico: $21^{\text {st }}$ Century Editorial.

Furnham, A. (1982). Explanations for unemployment in Britain. European Journal of Social Psychology, 12, 335-352. https://doi.org/10.1002/ejsp.2420120402

Furth, H. (1980). The World of Grown-Ups: Children's Conceptions of Society. New York: Elsevier North Holland.

García de Quijano, M. (2000). El mundo laboral, el tiempo libre y el dinero [Labor world, free time and money] (5th ed.). Bogotá: Universidad de la Sabana.

Goldsmith, R. \& Goldsmith, B. (2006). The effects of investment education on gender differences in financial knowledge. Journal of Personal Finance, 5, 55-69. Retrieved from https://www.researchgate.net/publication/268341254

Guerra, M. (2005). Los jóvenes del siglo XXI, ¿para qué trabajan? Los sentidos del trabajo en la vida de jóvenes de sectores urbano-populares de la ciudad de México [21st century young people: what do they work for? Meaning of work in the lives of young people from Mexico City's urban \& popular sectors]. Revista Mexicana de Investigación Educativa, 10(25), 419-449. Retrieved from http://www.redalyc.org/articulo.oa?id=14002507 
Guzmán, G. (2000). ¿Qué es el dinero? Un abordaje desde la Psicología Económica [What is money? An approach from Economic Psychology]. Psicología desde el Caribe, 6, 75-92. Retrieved from http://ciruelo.uninorte.edu.co/pdf/psicologia_caribe/06/6\%20Que_es_el_dinero.pdf

Hidalgo, C. \& Abarca, N. (1990). Desarrollo de habilidades sociales en estudiantes universitarios [Development of social skills in university students]. Revista Latinoamericana de Psicología, 22, 265-282. Retrieved from http://www.redalyc.org/pdf/805/80522205.pdf

Hira, T., \& Mugenda, O. (2000) Gender Differences in Financial Perceptions, Behaviors and Satisfaction. Journal of Financial Counseling and Planning, 13, 86-92. Retrieved from https://www.researchgate.net/profile/Tahira_Hira/publication/242079683_Gender_Differences_in_Financial _Perceptions_Behaviors_and_Satisfaction/links/53dfc8520cf2aede4b493e-2c/Gender-Differences-in-Financi al-Perceptions-Behaviors-and-Satisfaction.pdf

Kehm, B. (2011). La gobernanza en la enseñanza superior: Sus significados y su relevancia en una época de cambios [Governance in higher education: Its meanings and its relevance in an era of change]. Barcelona: Octaedro.

Lauer-Leite, I., Colino, C., Da Rocha, E., \& Lauer, I. (2005). Socialização econômica: Conhecendo o mundo econômico das crianças [Economic Socialization: knowing the children's economic world]. Estudos de Psicología, 15, 145-152. Retrieved from http://www.scielo.br/pdf/epsic/v15n2/03.pdf

Lenor, R. (1974). Les exclus: Un Francaise sur dix [The excluded: One in ten French]. París: Editions du Seuil.

Lewis, A. \& Scott, J. (2000). The economic awareness, knowledge and pocket money practices of a sample of UK adolescents: A study of economic socialisation and economic psychology. Children's Social and Economics Education, 4, 34-46. https://doi.org/10.2304/csee.2000.4.1.34

Lewis, A., Webley, P., \& Furnham, A. (1995). The New Economic Mind. New Jersey: Prentice Hall.

López, M. (2014). Democratización de la educación superior en Colombia: Un análisis exploratorio [Democratization of higher education in Colombia: an exploratory analysis]. Revista CS en Ciencias Sociales, Revista, 13, 215-262. https://doi.org/10.18046/recs.i13.1825

Lovisolo, H., \& Tavares, T. (2014). Voces disonantes: Esfuerzos, innovación y el peso de la tradición. [Dissonant voices: efforts, innovation and the weight of tradition]. Revista de Ciencias Sociales, 25(otoño), 219-229. Retrieved from http://www.unq.edu.ar/catalogo/330-revista-de-ciencias-sociales-n-25.php

Lunt, P., \& Furnham, A. (Eds.) (1996). Economic socialization: the economic beliefs and behaviours of young people. Cheltenham: Edward Elgar.

Margulis, M. \& Urresti, M. (1996). La juventud es más que una palabra [Youth beyond a single word]. In: Margulis (Ed.), La juventud es más que una palabra [Youth is more than a word]. Buenos Aires: Ed. Biblos.

Marshall, H., \& Magruder, L. (1960) Relations between parent money education practices and children's knowledge and use of money. Child Development, 31(June), 253-284. https://doi.org/10.4236/psych.2017.88078

Martínez, J. (2010). La universidad productora de productores (21st ed.) [The university producer of producers]. Bogotá: Universidad de La Salle.

Maslow, A. (1991). Motivación y personalidad (2nd ed.) [Motivation and personality]. Madrid: Ed. Díaz de Santos.

Mathieu, V. (1990). Filosofia del dinero [Philosophy of money]. Madrid: Ed. Rialp.

Melo, B., Ramos, F., \& Hernández, S. (2014). La educación superior en Colombia: situación actual y análisis de eficiencia [Higher education in Colombia: current situation and efficiency analysis]. Borradores de Economía, 808. https://doi.org/10.13043/dys.78.2

Millan, P. (1974). Economía y libertad [Economy and freedom]. Madrid: Cave Books.

Núñez, V. (2002). La educación en tiempos de incertidumbre. Las apuestas de la Pedagogía Social (1st ed.) [Education in times of uncertainty. The gamble of Social Pedagogy]. Barcelona: Editorial Gedisa.

Olivella, M. (1992). El poder del dinero. La monética, factor de cambio politico [The power of money. Monetics, factor of political change]. Barcelona: Edicions 62 S.A.

Ortíz, M., \& Morales, M. (2011). La extensión universitaria en América Latina: concepciones y tendencias [University Extension in Latin America: Concepts and Trends]. Educación y Educadores, 14, 349-366. 
https://doi.org/10.5294/edu.2011.14.2.6

Osuna, S. (2008). Publicidad y consumo en la adolescencia [Advertising and consumption in adolescence]. Barcelona: Icaria Editorial.

Pedersen, J. (1960). Teoría y política del dinero (3rd ed.) [Theory and politics of money]. Madrid: Aguilar.

Pinilla, S., \& Lugo, A. (2011). Lo público como espacio de lo común ampliado: significados y prácticas de organizaciones y redes juveniles en Colombia [The public as an expanded common space: meanings and practices of youth organizations and networks in Colombia]. Colombia: Century of Man Editors.

Pyöriä, P., Ojala, S., Saari, T., \& Järvinen, K. (2017). The millennial generation: A new breed of labour? SAGE Open, 7(1), 1-14. https://doi.org/10.1177/2158244017697158

Quintana, J. (1997). Por una pedagogía humanista [Toward a humanistic pedagogy]. Madrid: Dykinson.

Ramos, J. (2010). ¿Qué es el dinero? [What is money?]. Navarra: EUNSA.

Reyes, V (2011). El significado social del dinero [Social meaning of money]. Revista Colombiana de Sociología. 35, 187-192. https://doi.org/10.15446/rcs

Rinaldi, E., \& Bonanomi, A. (2011). Adolescents and money: Values and tools to handle the future. Italian Journal of Sociology of Education, 3, 86-121. http://doi.org/10.14658/pupj-ijse-2011-3-6

Rinaldi, E., \& Todesco, R. (2012). Financial literacy and money attitudes: Do boys and girls really differ? A study among Italian preadolescents. Italian Journal of Sociology of Education, 4(2), 144-165. http://doi.org/10.14658/pupj-ijse-2012-2-9

Rinaldi, E. (2007). Giovani E Denaro Percosi di socializzazione económica [Paths of economic socialization] Milano: Edizioni Unicopli.

Rodríguez, A., Bernal, A., \& Urpi, C. (2005). Retos de la educación social [Challenges of social education]. Spain: Edition Eunate.

Rojas, J. (2006). Homologación y reconocimiento de títulos de educación superior en Iberoamérica [Degrees' homologation and recognition in Ibero-American higher education]. Organización de Estados Iberoamericanos. (OEI). Retrieved from http://www.oei.es/homologaciones/colombia.pdf

Scheler, M. (2001). Ética. Nuevo ensayo de fundamentación de un personalismo ético [Ethics. New essay on the foundation of an ethical personalism]. (Juan Miguel Palacios Edition). Madrid: Caparrós Editors.

Von Mises, L. (1936). La teoría del dinero y del crédito [Theory of money and credit]. Madrid: M. Aguilar-Editor.

Wilkis, A., \& Partenio, F. (2010). Dinero y obligaciones generizadas: las mujeres de sectores populares frente a las circulaciones monetarias de redes políticas y familiars. [Money and gendered obligations: women of popular sectors facing monetary circulations of political and family networks]. La ventana, 4(32), 177-213. Retrieved fromhttp://www.scielo.org.mx/scielo.php?script=sci_arttext\&pid=S1405-94362010000200007\& lng=es\&nrm=iso

World Bank. (2000). Higher Education in Developing Countries Peril and Promise. Washington DC: World Bank.

Zelizer, V. (1989). The social meaning of money: "Special Money". The American Journal of Sociology, 95, 342-377. https://doi.org/10.1086/229272

Zelizer, V. (1994). The Social Meaning of Money: Pin Money, Paychecks, Poor Relief, and Other Currencies. New York: Princeton University Press.

Zelizer, V. (2009). La negociación de la intimidad [Negotiation of intimacy]. Buenos Aires: Fondo de Cultura Económica.

Zelizer, V. (2011). El significado social del dinero [Social meaning of money]. Buenos Aires: Fondo de Cultura Económica.

\section{Copyrights}

Copyright for this article is retained by the author(s), with first publication rights granted to the journal.

This is an open-access article distributed under the terms and conditions of the Creative Commons Attribution license (http://creativecommons.org/licenses/by/4.0/). 